
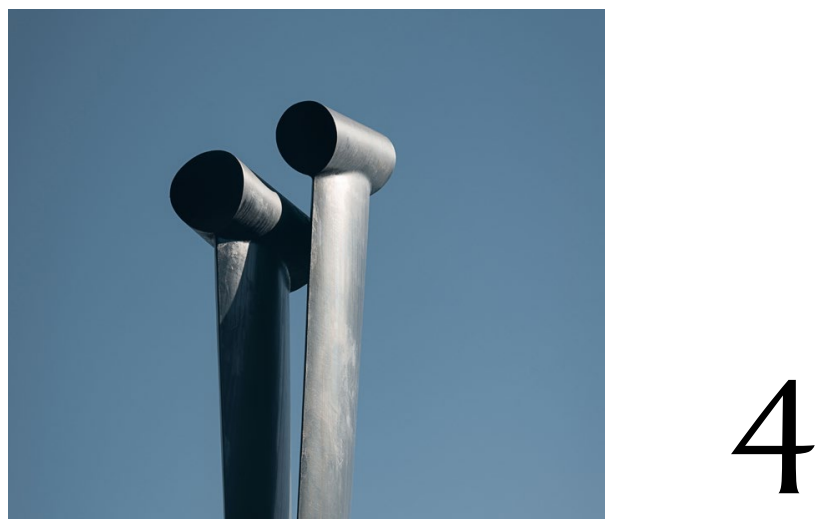

\title{
RACIAL CLASSIFICATION AND THE SPECTRE THAT HAUNTS
}

\author{
Handri Walters
}

Ruins are not just found, they are made.

Benjamin Dawids was 42 years of age, born of mixed descent to "European" and "Hottentot" parents in Stellenbosch (according to his data sheet). The Von Luschan table indicated that Benjamin's skin colour measured between numbers 9 and 18 for the various parts of his body. Fischer's table indicated that his hair colour corresponded to number 4, while his eye colour corresponded to number 2 on Martin's table. ${ }^{1}$ Further measurements detailed the shape of Benjamin's head and the characteristics of his face and nose. The prognathy of the jaw measured 2 on a scale of $0-5$. His nose had a narrow root, medium and straight bridge, a downwardly directed tip, a short and narrow septum, and an obliquely oval, wide and large opening. His face was round and moderately flat. Further observations noted his spindle-shaped eyes, thin lips and large, yellowish teeth; his large, broad and flat feet,

1 Felix von Luschan's skin colour table was designed in 1905, Eugen Fischer's hair colour table in 1907, and Rudolf Martin's eye colour table in 1903. 
and his thick long fingers with bluish nails. Benjamin had tattoos on his left upper and lower arm, and a scar adorned his right thigh. On 22 October 1937, Benjamin Dawids was the first of 133 coloured males to be meticulously measured by staff members and students of the Zoology Department of Stellenbosch University. ${ }^{2}$

It was a summer's afternoon in February of 2013, when I was confronted with the instruments used to measure Benjamin Dawids (and many others) in a corner office of the Stellenbosch University Museum. A silver casing bearing the name of Eugen Fischer, opened to reveal 30 strings of synthetic hair ranging from dark to light, from straight to curly, was placed on the table in front of me. This was followed by a bruised and battered metal box reading Augenfarbe along with the name of Rudolf Martin on its sliding metal lid. Upon my opening the metal box, 16 eyes stared back. And, finally, a human skull wrapped in tissue paper was placed on the table. The recognition of the historical use of these objects was instantaneous. The taken-for-granted nature of such recognition and of supposed "race knowledge" in general was suddenly revealed in all its problematic proportions. Confronting these objects evoked what Freud would refer to as "the uncanny" (unheimlich). While the uncanny can be related to that which arouses "dread and creeping horror" (Freud, 1919) or evoke a sense of uncertainty, Freud (1955 [1919]:229-230) conceptualises the uncanny as "something familiar and old", something "established in the mind that has been estranged only by the process of repression". Simply said, the uncanny signifies the return of the repressed. For Freud, an uncanny feeling is experienced "in the highest degree in relation to ... the return of the dead, and to spirits and ghosts" (Freud, 1955 [1919]:230). The uncanny in this sense is evoked by a ghostly presence.

The measurements and methods employed to measure Benjamin Dawids in 1937 were broadly used in worldwide physical anthropology during the early twentieth century to determine racial characteristics and racial affinity. ${ }^{3}$ For many scientists

2 While anonymisation has historically been used to safeguard the identity of vulnerable persons, it simultaneously has the effect of dehumanising and alienating these individuals. Thus, throughout this chapter, the full names of those measured by the Zoology Department in 1937 is used as it appears on the data collection sheets - documents that are open to the public. The use of the full names is here employed to humanise those who were subjected to, and objectified by, a scientific gaze. Similar arguments for the use of full names have been made by Rory du Plessis (2015) and Julie Parle (2007) in relation to their work dealing with pathological subjects.

3 The subject matter of this chapter requires an extensive footnote on the use of race. In the social sciences, the broad consensus, for the better part of a century now, has been to regard race as a social construction - a turning point that occurred when UNESCO proclaimed race to be a myth in 1952. Since then, writings on race within the social sciences have had to provide a (by now) familiar disclaimer to distance the use of racial terms from ideas that these relate to biological difference. In addition to such disclaimers, many a text has made 
at the time, separate human races were natural biological entities of which the characteristics "were essential and given" (Winant, 2000:174). In this regard, visible characteristics, generally referring to the complexion of the skin, the colour of the eyes, the colour and texture of the hair, and general features of the face, became the primary sources for racial classification (Wilder \& Wentworth, 1918:61). Standardised practices for anthropometric measurements developed and internationally prescribed between 1910 and 1914 aided this process of classification (Grobbelaar, 1948:53; Van Wyk, 1939:61). The development of the skin colour, the eye colour, and the hair colour and texture tables, respectively, in the early twentieth century, similarly aided these forms of classifications based on visible physical characteristics. ${ }^{4}$ The methods for classification stemmed from Linnaean typology and rested on a notion of natural racial groupings based on the Aristotelian logic of a fundamentum (a particular character) shared by every member of the group (Daly, 1961:176). Racial groupings were thus divided by the appearance of common characters found in this group. While not all members of the group possessed exactly the same characteristics, the notion of aggregates, or the "estimate of the degree of overall similarity" (Daly, 1961:176), were employed to categorise individuals into the main racial groupings. This logic would have far reaching consequences for racial classification and the implementation of race-based policies around the world (Ford \& Airhihenbuwa, 2010:S30).

use of quotation marks when writing the very word "race" to indicate the constructed and contentious nature of the concept. Similar rules have applied for the expression of racial categories - using quotation marks to highlight the problematic nature of naming groups along lines of racial difference. Following the arguments made by David Theo Goldberg (2016), Gerhard Maré (2014) and W.J.T. Mitchell (2012), I will not make use of "scare quotes" when referring to race. I accept that race is indeed a social construction, and I ask my reader to remember this as they engage my work. The use of designated racial categories in the South African context offers another dilemma. The risk of writing about racial categories is the perpetuation of the power located in the continued use of words that differentiate along lines of race. The word alone gives power to its meaning. As argued by Derrida in 1978, we are left with "the restrained and restraining language of Western reason ... Nothing within this language, and no one among those who speak it, can escape" (cited in Comaroff and Comaroff, 1992:15). In South Africa, we remain constrained by a continued use of apartheid-era racial categories. In this chapter, I attempt to offer a response. Similar to the way in which we have de-capitalised apartheid in order to disempower as well as delegitimise not only the word but the ideology behind it, all racial designations will be de-capitalised in this text. In defiance of the rules of grammar, I attempt to strip these words of their power while simultaneously acknowledging their continued existence, use, and very real effects in society.

4 Marketed specifically for scientists and researchers (Powerhouse Museum Collection, 2015), the tables were manufactured by Artur Gneupel in Zurich, Switzerland (Grobbelaar, 1956:107) and sold by P. Hermann at 71 Scheuchzerstrasse, Zurich, for a "moderate price" (Eye table, \$15.00; Hair table, \$6.50; Skin table, \$2.50) (Wilder \& Wentworth, 1918:68). 
In the South African context, the study launched by the Zoology Department of Stellenbosch University came in the midst of an increased interest in the coloured population during a political climate of rising Afrikaner nationalism, racial division, and a road paved for the establishment of the apartheid government. This study attempted to offer a scientific engagement to determine the racial make-up of the local coloureds. The extent to which "scientific" engagements informed the constitution of racial categories as implemented by the apartheid state have been addressed and for the most part dismissed by Saul Dubow (1995, 2010, 2014) and Deborah Posel (2001) - two authors regarded as authorities on the issue. Taking heed of its unavoidable presence in the "obsession with purity of blood" Dubow (2010) argues for the selective use of racial science in the development and implementation of the apartheid state. By no means a definitive presence, racial science is viewed by Dubow as a "scavenger piece" - a tool to be implemented by the apartheid state if, and when, needed. Posel (2001) on the other hand argues for a "strategic ambiguity" maintained by the apartheid state in the conceptualisation and implementation of racial categories. In this regard, Posel (2001:101) argues for an unuttered acknowledgement on the side of the state that "scientific precision in the definition of race" would be "detrimental to the project". Yet, in the decades preceding the implementation of apartheid, there was a concerted effort to determine and cement the coloured category through scientific contributions, stemming from the fields of physical anthropology, the medical sciences, and psychology.

Posel and Dubow both argue for a fluidity and ambiguity in the conceptualisation and application of racial categories in apartheid South Africa - something that can hardly be contested. However, whether this was a strategic manoeuvre on the part of the state becomes a curious point of contestation when the spotlight is placed on the engagements with the coloured population under the apartheid government. Here the government was confronted with a population closely aligned to the white European, so close that many were able to "pass" for white. The inherent threat such "passing" posed to racial purity and the political and economic power of "white Europeans" required careful regulation. It also required a persistent engagement with the coloured population to formulate and define this category as different, and separate, from whites. The increased interest in racial difference thus spoke to an ever-increasing need to regulate and control populations deemed threatening for the continued existence and ensured power of a white minority. In this regard, the coloureds posed a particular problem to clear-cut categorisations and, more importantly, as separate and different from whites.

Coloureds were first recognised as a separate group in Cape Town towards the end of the nineteenth century, but it was particularly in the 1930s that the concerns with racial distance (and miscegenation) with regard to coloureds manifested in 
academic debate and government action. Deemed a source of danger (posing a threat to the preservation of whites), the possibility of coloureds passing for white was also seemingly a source of great paranoia. In 1936, George Findlay proclaimed that a large number of individuals that should be classified as coloured had somehow passed as "white". In this sense, Findlay's 1936 publication, Miscegenation: A study of the biological sources of inheritance of the South African population, caused quite a stir. ${ }^{5}$ This was followed by the published results of the Commission of Inquiry Regarding Cape Coloured Population of the Union (more commonly known as the Wilcocks Commission). The Commission offered a comprehensive report of the coloureds in 1937 - a report that also became one of the catalysts for a deeper social scientific engagement with this population at government level (Jensen, 2008:21). ${ }^{6}$ The decades following this moment marked a heightened interest in the coloureds especially in the Cape Province where this population was predominantly located. Later rather vaguely defined as "not a white person or a native" by the Population Registration Act, No. 30 of 1950, the racial designation of coloured remains unique to South Africa.

\section{The formation of subjects: a coloured category}

Michel Foucault argues that "the subject does not exist as a determinate form with specific qualities before the practices that made up the 'rapport à soi' bring it into being" (quoted in Olssen, 2010:65). Foucault spoke to the social construction of categories - or rather, he spoke of categories as something to be constructed. The construction of categories become of particular importance when related to the state or modern power. In this regard, Colin Jones and Roy Porter (1994:99) described the "peculiarity of modern power" as operating by "producing the subject" that becomes "the target of other strategies". It relates to Albert Memmi's (1965:71) notion of colonial power: to first establish something as "an 'absolute fact' [after which] colonisers are free to exploit it for their own benefit”. For instance,

5 At the time, Findlay's publication was deemed important enough to motivate an Afrikaans translation, Bloedvermenging. Swart en wit in Suid-Afrika: die faktore wat bloedvermenging vertraag of versnel (translating to: "Miscegenation. Black and White in South Africa: the factors that delay or accelerate miscegenation" - the title not being a direct translation of the original, but reformulated to appeal to an Afrikaans audience).

6 Over the course of the next decade, this was followed by the Commission of Inquiry into Mixed Marriages in South Africa, UG nr. 30, 1939; Committee of Inquiry nominated to investigate conditions on the Cape Flats and in areas in the Cape Division where similar conditions prevail, 1942; the Cape Coloured Liquor Commission in 1945; the Interdepartmental Committee on Coloured Relations, Coloured Mission Stations, Reserves and Settlements, UG nr. 33, 1947; and the Commission of Inquiry into Deviate Children (Non-European) in 1950. 
Christopher Bracken (1997) illustrated how colonial correspondence constructed the North American potlatch. He argues that "the legal text gave administrators a potlatch to regulate" (Bracken, 1997:228).

For Foucault (quoted in Faubion, 2001:326), classification is deemed a technology of domination through "dividing practices", where - the individual is divided from others and objectified by the state. In his analysis of the modern state, James Scott (1998:77) emphasises the importance of reducing "a large and complex reality" to a "legible landscape" - in other words "an infinite array of detail" needs to be reduced "to a set of categories that will facilitate summary descriptions, comparisons and aggregation" (Scott, 1998:77). The creation of categories and the act of classification becomes of key importance for a state-wide "legible landscape" - mad, sick, healthy; developed, underdeveloped; civilised, uncivilised; white, black, coloured, indian. Through prolonged implementation, categories that were once "artificial inventions" can become "categories that organise people's daily experience" (Scott, 1998:82-83). For Ann Stoler (2008:202), such "imperial projects" are defined as "state projects that require resources and planning [and dictate] how people are supposed to live", and have the propensity to "bring ruin upon [and] exert material and social force in the present" (Stoler, 2013:11). Imperial projects embody the longitudinal - a patient project stretching over decades, centuries even. It is persistent in its implementation, it is allowed to gain momentum, it is allowed to continue until it is no longer questioned, until the project itself and the results it renders become taken for granted or gain the force of simple habits of mind. These longitudinal imperial projects are bound to produce ruins - the severity of their effects located in their most unassuming forms.

Over the course of 1937, 133 coloured males of the Stellenbosch area were subjected to detailed observations and measurements (each providing a sum of 80 measurements of the corporeal body). In this regard, the standardised measurements, as globally prescribed by Rudolf Martin's Lehrbuch der Antropologie (1914), were applied. The data sheets contained the name, sex, age, place of birth, place of residence, and maternal and paternal descent of the subject. Skin, eye, and hair colour (as found on various parts of the body) were determined by using the tables respectively designed by Fischer, Martin and Von Luschan. Further observations were made regarding the "types" of the head, face, nose, jaw, lips, teeth and ears. A section titled "special observations", very reminiscent of Alphonse Bertillon's (1895) identification of criminals by individual characteristics such as scars and tattoos (in addition to visible innate physical characteristics and measurements of the head and body), was left open for the researcher to complete at their own discretion. This particular section contained all kinds of information from tattoos to bodily scars, comments on cleanliness, and personal observations 
related to the individuals' perceived intelligence. It is particularly within the section designated for special observations that the assumptions, racial stereotypes, and slanted interpretations of those entrusted with the data collection process (C.S. Grobbelaar and his students) became evident. Klaas Fram was labelled as "very stupid" (baie onnosel); Gert Rippenaar was described as "not too clean!"; Berend Solomon had "many cut wounds due to stabbings" (baie snyplekke as gevolg van messteke); Arnold Maart was described as a "very typical coloured - farmboy and pretty stupid" (baie tipiese kleurling - plaasjong en taamlik onnosel); Willie Abrahams, of white and hottentot descent, had a "very intelligent face ... a long thin face" (baie intelligente gesig ... lang dun gesig); Abram Abrahamse, on the other hand, had a "very uncivilised face" (baie onbeskaafde gesig); while Gert Bekker, of European and "a bit of hottentot" descent was simply "a bad example of a human being" ('n swak voorbeeld van ' $n$ mens) (Department of Zoology, 1937).

The engagement came from the standpoint of physical anthropology - at that time a field of study housed by the Zoology Department under the guidance of Professor C.G.S. (Con) de Villiers and Dr C.S. (Coert) Grobbelaar. ${ }^{7}$ Both had received their doctoral training in Europe in the early 1920s - De Villiers in Zurich and Grobbelaar in Berlin. At the Zoology Department of Stellenbosch University, they introduced a course on practical anthropometry in 1924 and prescribed Rudolf Martin's Lehrbuch der Anthropologie (Handbook for Anthropology), Wilder's Laboratory Manual of Anthropometry, and the English translation of Boule's Les Hommes Fossiles (Fossil Man) for the course. In addition to the prescribed literature, the instruments developed by Martin were used (Stellenbosch University [Calendar], 1924:195). The course at Stellenbosch University was seemingly informed by the discipline's international roots. It was particularly Grobbelaar who pursued studies of the physical-anthropological kind. Deeply influenced by his German training, Grobbelaar envisioned a great role for physical anthropology, more specifically the "practical applications" of anthropometric studies in South Africa (Grobbelaar, 1948:53). Citing Eugen Fischer, Grobbelaar (1948:53-54) stated the body's physical constitution was heritable and that specific characteristics within the body were often linked to a particular race. In this regard, racial differences in the physical constitution of the "European population, of the Coloured Races and of the Bantu" (Grobbelaar, 1948:53) was envisioned as an avenue for possible groundbreaking contributions by the field of physical

7 The roots of physical anthropology are to be found in a variety of disciplines, but once it gained autonomy and was offered as a field of study at universities it mostly fell within the realm of the medical sciences (Morris, 2012). At Stellenbosch University, where no medical faculty had yet been established, the Zoology Department offered courses in comparative anatomy and introduced physical anthropology as a subject. 
anthropology to South African policy development. ${ }^{8}$ The studies produced by the Zoology Department as related to physical anthropology between 1925 and 1960 addressed racial categories in terms of racial constitution and racial difference.

In South African physical anthropology, the study of racial types and "the origins of the Southern African peoples", was very common during the first half of the twentieth century (Morris \& Tobias, 1997:969). Notable academics who committed their energies to this field of study included Matthew Drennan of the University of Cape Town, Raymond Dart of the University of Witwatersrand, T.F. Dreyer of the University of the Orange Free State, and Robert Broom, who had taught in the Zoology Department of Stellenbosch University, then Victoria College, between 1903 and 1910 (Morris \& Tobias, 1997:969). It was particularly the relation of the modern races to ancient types that became the focus of these academics - most notably illustrated by the engagements with, and debates about, the so-called "Boskop skull" found in 1913 (Morris, 2008). This included the identification and categorisation of racial types as found in Southern Africa more particularly the non-European populations of South Africa - and inherently engaged arguments for the biological distinctiveness of certain categories. Following Crain Soudien (2006:56) in his analysis of the making of bantu identity in South Africa, it could similarly be argued, the engagements with the coloured population involved the empirical recognition of a human category which then became "systematically classifiable and, like any zoological species, available as an object of knowledge for inspection and analysis" (Soudien, 2006:56).

The data collected during 1937 were eventually published in 1939 as "A preliminary account of the physical anthropology of the 'Cape Coloured People' (Males)" with a focus on "the purely physical characteristics of the Coloured population" (Van Wyk, 1939:61). Here the bodily summation, framed as "typical" characteristics to be found in the research subjects (and thereby extended to an entire coloured category), included "a lighter complexion" (relative to the hottentot or bantu), brown eye-colour, woolly dark hair, and a flat nose with a broad nasal root, amongst other characteristics. For Van Wyk (1939:5), "European blood seemed to be obviously present in the Coloured People". The undeniable presence of European blood was apparently revealed through the relative height of the subjects (inheriting the taller stature of the European) and the shape and size of the nose (which revealed traces of the narrower and higher nose of Europeans) (Van Wyk, 1939:50, 55).

While the relative closeness of the coloured subject to the white European was identified, the study mostly provided the scientific underpinnings for a population

8 For Grobbelaar (1948:60), these policies would ensure "the preservation and development of the most valuable genetic types of the population". 
that was to be considered as separate and different from whites and supported the conclusion with the work of German anthropologists and eugenicist Eugen Fischer (1913). Fischer's The Rehoboth Bastards and the Problem of Miscegenation among Humans particularly focused on hybrid populations resulting from racial mixture and intermarriage between the hottentot and European colonists. For Fischer (1931:114), "the tint of the skin, the growth of the hair, the shape of the nose, the lips, and the skull" were seen to illustrate the "plainly inheritable differences" aiding the division of groups into races (Fischer, 1931:165). He concluded that "all European nations which have undergone the infiltration of inferior blood have had to pay for this sin by an appreciable decline in their intellectual and cultural standards" (as quoted in Hertz, 1928:131). Fischer's work, as highlighting "negative outcomes of racial intermixture" (Venter, 2009:124), was often cited during the 1930s and 1940s (and even beyond) by South African academics in relation to the coloured question. The coloured may have been the result of racial mixture, but through scientific engagements the category was transformed into a unique hybrid racial category with measurable racial characteristics (read "separate racial category").

The coloured population remained a source of interest to the Zoology Department of Stellenbosch University. In 1959, J.S. van der Spuy, a student in the department, compared the physique and growth of white and coloured boys between the ages of 13 and 17.9 A total of 474 white European boys and 500 coloured boys were measured (Van der Spuy, 1959:69). Van der Spuy (1959:67) found the white European boys to be taller than the coloured boys with significant statistical differences to be found between the two groups. The white boys were also found to be larger in their physique and greater in their weight (Van der Spuy, 1959:135, 136). While Van der Spuy (1959:138) stated that the coloureds were often viewed as a more heterogeneous group (due to miscegenation), through measurements and observations of physical characteristics he found this group to be very homogeneous indeed.

Van der Spuy's study on the physique and growth of white and coloured boys was published at the end of the 1950s and much had transpired during this decade. By this time, the scientific information comprising more insights into the coloured had emerged. In 1952, Dr J.A. Keen of the University of Cape Town published a "Craniometric Study of the Cape Coloured Population". Keen (1952:40) found "the mean for the male Cape Coloured skull [to be] well below the European group, but above that of the male bantu". The results were based on the measurement

9 See "'n Studie van die liggaamsbou en liggaamsgroei van blanke en kleurlingseuns in die Westelike Provinsie, ouderdomsgroep 13 tot 17 jaar" (A study of the physique and growth of white and coloured boys in the Western Province, age group 13 to 17 years). 
of 141 adult male skulls obtained from "dissecting-room cadavers" in the Department of Anatomy. Regarding the coloureds as "a distinct ethnic group" (Keen, 1952:29), and one that was "as homogeneous as two of the parent racial groups" (1952:50), Keen (1952:42) proclaimed the cranium to be "neither typically Bantu, nor typically Hottentot; [and] certainly not European”. The study, produced shortly after the Population Registration Act of 1950 was introduced by the apartheid government, provided scientific reinforcement for the existence of the coloured as a separate racial category. The measured difference in skull size offered by Keen (1952) spoke to an existing debate regarding the intelligence of coloureds as related to whites and natives. In this regard, M.L. Fick (1929) argued for a racial hierarchy based on mental capabilities with the "coloured" occupying a middle position (achievements higher than natives but lower than "whites"). Stellenbosch student Frederich Albertus Sadie similarly drew correlations between the presence of "European blood" and learning capability in The Relation between the learning ability and the degree of European blood in SA Non-Europeans (1942) - with a greater degree of European blood resulting in a greater learning ability. A.P. Blignaut (c.1940), another Stellenbosch student, also found the learning ability of whites to be superior to coloureds who were in turn superior to natives. ${ }^{10}$

Continued attempts to provide scientific justifications for the acceptance of coloured as separate and different from whites and natives transpired in many disciplines in the 1940s and 1950s. By the early 1950s, there was seemingly hardly a need to elaborate anymore when the Stellenbosch-based South African Bureau for Racial Affairs (SABRA) argued the differences between whites, coloureds and natives were "obvious" as related to culture, language, psychology, and biological race (SABRA, 1953:30-31). These decades also provided great political change in South Africa. The National Party came to power in 1948 - officially bringing forth the apartheid state. This was followed by the introduction of the Prohibition of Mixed Marriages Act (1949), the Population Registration Act (1950), the Immorality Amendment Act (1950), the Separate Representation of Voters Act (1951), the Group Areas Act (1952), and the Reservation of Separate Amenities Act (1953). Each of these laws would cement, at least in practice, a racial divide between white and coloured. Yet, even in the aftermath of implementing these laws, there remained a continued interest in confirming the hybrid category of coloured as racially separate from white - thereby assisting in the implementation of stricter state controls over, and regulation of, these categories. In the early 1950s, even after

10 See unpublished MA thesis submitted to the Psychology Department of Stellenbosch University: "The Learning Capability of the Graaff-Reinet Coloured compared with that of the Europeans and Natives" (Die Leerbekwaamheid van die Graaff-Reinetse Kleurling in vergelyking met dié van die Blanke en Naturel). 
the implementation of apartheid laws, the state was dealing with a category that was not only broadly accepted as a demarcated, essentialised and homogenised category written into law, but also one which seemingly evaded clear-cut definitions or markers for categorisation. This was partly evidenced by continued attempts during the 1950s to define the coloured category more concisely. In this regard, an interdepartmental committee was appointed to produce "a basic definition which would be a 'master-definition' applicable to all laws requiring racial definition" (Dönges, 1959). The minister of the Interior, Dr Eben Dönges, unfortunately had to report back to parliament after 30 months that the committee "could not find a basic legal definition" (Dönges, 1959). The category of coloured was accepted, yet undefined (and seemingly undefinable).

In the absence of a clear-cut definition, the state pushed forward. At Stellenbosch University, the coloured question took precedence in the 1950s. The Stellenboschbased SABRA dedicated considerable energy towards further investigations of this category of people. In this regard, two annual conferences were dedicated to the cause: "What is the future of the coloured?" (Wat is die toekoms van die kleurling?) in 1954, and "The coloured in South African society" (Die kleurling in die Suid-Afrikaanse samelewing) in 1955. This was followed by the independent establishment of an interdisciplinary research committee at Stellenbosch University in 1955 to provide an encompassing study of the Western Cape area with a focus on the Cape coloured and the native population in this area. ${ }^{11}$ The Western Cape Research Project (Wes-Kaaplandse Navorsingsprojek or WKNP) enjoyed government attention from its inception and was funded by the National Council for Social Research for a period of three years, 1956-1958. Attended by a number of important stakeholders, the first meeting revealed broad government interest in the project and its results. The Division for Coloured Affairs (later the fully-fledged Department of Coloured Affairs), the Department of Native Affairs, and the Department of Home Affairs all sent representatives to attend (Eikestadnuus, 1955:1).

Although the "ethnic demarcation" of coloured was seemingly to be determined by the committee, an existing conceptualisation of this population drove the study. Johannes Petrus van Schalkwyk (Hannes) Bruwer, head of the Department of

11 The following lecturers represented their departments on the committee:

Prof. C.G.W. Schumann (Business Economics), and director of the project; Prof. J.L. Sadie

(Economics and Demography); Prof. P. Serton, Prof. A. Nel, and Dr D.J. Conradie

(Geography); Prof. P.E. de Waal (Agriculture); Prof. N.J.J. Olivier (Native Administration);

Prof. P.S. du Toit (Education); Prof. E. Theron and Prof. S.P. Cilliers (Sociology and Social

Work); and Prof. J.P. Bruwer (Volkekunde) (Cilliers, 1964:4). 
Volkekunde ${ }^{12}$ and tasked with the responsibility of developing a research scheme for the project (Bruwer, 1956), reported back to the committee on 3 June 1956:

[...] a somatic survey of the Coloureds does not justify the estimated expenditure of $£ 500$. Therefore, the Department of Volkekunde will not launch a comprehensive investigation in this regard, but could rather get valuable information from studies conducted by the Department of Zoology. (Bruwer, 1956) [my translation]

In this regard, the 133 coloured males measured over the course of 1937 came to be regarded as the accepted embodiment of a coloured category. Seemingly deeply influenced by notions of race as found in pre-World War II physical anthropology, Bruwer regarded race as a biological entity and defined it as:

$[\ldots]$ a group or division of mankind having certain recognisable and inherited physical characteristics in common by which those individuals belonging to it can be distinguished from those belonging to other races, whose members will have their own peculiar and common physical characteristics.

(Bruwer, 1958:10-11)

Coupled with his skepticism of the UNESCO statements on race (see 1950 and 1952), Bruwer provided further evidence of his possibly "archaic" views on the subject matter when he referenced Fischer's hair texture and colour table, Martin's eye colour table, and Von Luschan's skin colour table as part of the methodology to "classify the main race groups of the world" (Bruwer, 1958:12). Here, the typical language of early twentieth-century racial science was drawn upon for distinguishing racial characteristics: wavy, straight or woolly hair was related to the various racial groups; the occurrence of blonde versus black hair, and dark versus light skin as related to the various races was highlighted; the occurrence of blue eyes as "practically confined to the Caucasian group" was mentioned; a reference was made to the narrow nostrils and high bridge of the nose for caucasians as opposed to the broad and flat nose with a low bridge found in the "Negroids" (sic); and the mention of the significance of the angle of the lower jaw (prognathy) and the cephalic index as found in the different races were all part of this discussion (see Bruwer, 1958:14-19).

12 "Volkekunde" is generally regarded as an Afrikaner brand of social anthropology (Sharp, 1981), taught at Afrikaans-medium universities. First established at Stellenbosch University in 1926, Volkekunde was eventually extended to all other Afrikaans-medium universities in South Africa. Historically, it has been clearly distinguished from the kind of social anthropology taught at English-medium universities. Much like the institutions it was part of, Volkekunde has often been linked with a conservative nationalist agenda, while social anthropology has been regarded as providing a more liberal approach. This is, however, a broad generalisation and simplification of academic engagements within these respective "camps". 
It comes as little surprise then that the man responsible for developing a research methodology for the Western Cape Research Project considered coloureds to be separate from whites and natives in a "race-biological sense" (Bruwer, 1964:101). The natural and non-negotiable nature of separate racial categories made the Population Registration Act a mere formality for Bruwer, who proclaimed that the "exist[ence] of various races in South Africa cannot be laid at the doorstep of the Act" (Bruwer, 1964:76). In the face of increasing criticism aimed at this Act due to the many individual classifications brought in front of the Review Board, Bruwer proposed more diligent research pertaining to individual classification (as opposed to questioning the existence of separate races) in order to guard against wrongful classification. With regards to definitions for the various racial categories, there was a truth to be found. The nature or the essence of the racial category was there to be discovered. This disposition was particularly significant in the context of policy development as it allowed a steadfast, non-negotiable approach to the reality of the designated racial categories of the apartheid state.

The research project at Stellenbosch University thus spoke to the particular political context of the 1950s, a time when there was a move towards a more strictly defined coloured population, and a more strictly defined position of this population within the apartheid state. An early result that stemmed from the project was the determination of the "Eiselen line" - a geographical demarcation for the control of native influx in the Western Cape area (the name inspired by its main proponent, secretary of Native Affairs, W.W.M. Eiselen). It came shortly after Eiselen announced his official stance at the 1955 SABRA conference: "All foreign Natives are gradually to leave the Western Province and no more of them are to be permitted in this region" (Eiselen, 1955:111). ${ }^{13}$ Coupled with minister of Native Affairs Hendrik Verwoerd's proposal that coloureds should enjoy labour preference in the Western Cape, the removal of the "native-element" was also considered to provide the opportunity for coloureds to pursue their status of distinctiveness. The removal of natives was thus also propagated to create a sense of identification with the coloured category which would allow this population "to develop as a distinct population with a sense of national pride" (nasietrots) (SABRA, 1955:128).

The WKNP's contribution to the position of coloureds in the Western Cape proved to be noteworthy, as the government's interest in this project did not dwindle. On 22 June 1959, the commissioner of Coloured Affairs, I.D. du Plessis, was reminded of the continued policy of coloured labour preference in written correspondence with the deputy minister of Labour and the secretary of Labour.

13 The distinction between coloured and native within labour law manifested legally in the Industrial Conciliation Act of 1956 when, for the first time, a distinction was made between coloureds and natives with regards to trade union membership and job reservation (SAHO, 2016). 
The inputs of the WKNP were cited as a significant contribution in this regard. The Department of Coloured Affairs seemingly also took notice and requested a sub-investigation into the viability of replacing native workers with a coloured labour force ("Komitee insake Arbeid in Wes-Kaapland", 1959). By September 1963, the secretary of Coloured Affairs, D.J. Bosman, announced the creation of local committees across the Cape Province charged with implementing the labour preference policy ("Komitee insake Arbeid in Wes-Kaapland", 1966). In this regard, the close ties between the WKNP and the relevant state departments were reasserted in 1965, one year after the official results of the WKNP study was published in book form, when the "Symposium Regarding Coloured Labour" was organised for these local labour committees. These local committees were all subsections of its more encompassing and province-wide title: Committee Regarding Labour in the Western Cape. The symposium was organised by Stellenbosch University in partnership with the Directorate for National Development and Management of the Western Cape Region (Streek Wes-Kaapland van die Nasionale Ontwikkelingsen Bestuursrigting). The one-day conference, entitled "The Mobilisation of Forces for the Development of the Western Cape" ("Die Mobilisasie van Kragte vir die Ontwikkeling van Wes-Kaapland"), communicated many of the ideas that had been developed by the WKNP and by SABRA (both Stellenbosch based) over the course of the previous decade. Here the Committee Regarding Labour in the Western Cape was treated to the insights of Stellenbosch academics and state officials with regards to the implementation of a coloured labour preference policy and an overall replacement of native labour with coloured and white labour (“Komitee insake Arbeid in Wes-Kaapland", 1966).

By this time, the Division for Coloured Affairs was converted in 1960 into the Department for Coloured Affairs, a full state department dedicated to coloureds with P.W. Botha appointed as the first minister of Coloured Affairs. The vague definitions that had transpired over the course of a few decades, and more particularly in the 1950s, definitions that spoke of conceptual failure, apparently did little to deter the acceptance of "coloured" as a separate racial category and the subsequent targeted implementation of policy. Once the category of coloured was created and accepted as "absolute fact" those who ruled were "free to exploit it for their own benefit” (Bracken, 1997:231).

The engagements of the previous decade by social scientists, built on the knowledge produced by physical anthropologists in the decades prior, had real and visceral effects in everyday life. As Robert Chia (2000:513) argues: “... [i]t is through this process of differentiating, fixing, naming, labelling, classifying and relating ... that social reality is systematically constructed." These effects were probably most evident in the large-scale forced removals of coloured populations during the 1960s 
and 1970s. Stellenbosch, the breeding ground for academic engagements with the coloured category, also became one of the first towns to implement Proclamation No. 211 as it appeared on 28 August 1964 in the Government Gazette. Less than a week after this announcement, Stellenbosch municipality proclaimed group areas in the town, and the process of forced removals was initiated. It was particularly the area near the centre of town that was proclaimed as a "whites-only" area. Predominantly occupied by coloureds at the publication of the proclamation, these areas were systematically cleared of coloured residents over the course of the next year. The apparent suddenness of the government's proclamation, which seemingly even took the town council by surprise, resulted in the establishment of Noodkamp (meaning emergency camp) 1 and 2, as liminal spaces for coloured residents before they were moved to the new coloured areas still being constructed on the outskirts of the town (here referring to Ida's Valley and Cloetesville, respectively).

By 1968, the emergency camps were still housing coloured families in about 100 shacks. A local resident by the name of Paul Edmunds brought the "hardships, [and] the minimal facilities available to these people and to the Municipality's refusal to help them move" to the attention of the town council and the readers of the local newspaper, Eikestadnuus. Meanwhile the vacated centre of town became the site for demolition, restoration and renovation - prepared for its new white occupants. The infrastructural development of Stellenbosch University, the institution that contributed in its own way to the construction of an identifiable coloured population, benefited in part from the forced removals. In June 1969, an architectural drawing of the new Education building (G.G. Cillié building) to be constructed on the corner of Ryneveld and Crozier streets graced the pages of the local newspaper. Construction was completed in 1970. By 1978, the construction of the new Arts and Social Sciences building (then known as the B.J. Vorster building) began on the corner of Ryneveld Street and Merriman Avenue. The predominantly coloured population who had once been located on this land, commonly known as Die Vlakte, had now been moved to the outskirts of town.

The coloured category had been successfully constructed and it had been done in the absence of clear-cut definitions. Yet, this category became the target of implemented policy - policy specifically developed for them. As Jensen (2008:17) argues, the apartheid government "ended up producing what it had asserted was there from the beginning, namely a coloured group". The visceral effects of these policies on the everyday lives of a population had little interest in the reality of the category it came to regulate. It simply regulated and controlled, taking no heed of its lasting effects and the grip it would impose on the future. As John Tagg (1993:4) argues: "What is real is not just the material item but also the discursive system of which [it] is part" - here speaking to "the conscious and unconscious processes" 
that underline "practices and institutions". In his letter to Eikestadnuus, Paul Edmunds concluded: "I would like to risk a generalisation about this town ... It seems to me that there are so many who have so much and there are so many with so little" (Eikestadnuus, 1968).

\section{A project of ruination}

The vague definition provided by the Population Registration Act No. 31 of 1950 and employed by the government, and the subsequent failure in the 1950s to narrow down a definition of coloured, did not discredit the existence of the category. Continued attempts by the government to provide more concise conceptualisations of the coloured category ultimately ended in failure and a vague definition of this category of people persisted. While Posel (2001) and Dubow (2010) would argue there was a strategic intent in keeping definitions vague and that this worked in favour of the apartheid government, the actions of the apartheid government in relation to the coloured category spoke of a desperate National Party that attempted, yet failed, to pin down a clear definition of a hybrid population. Definition or no definition, the racial categories of the apartheid state were accepted by the majority as real, and experienced as real. They continued to exude effects and repercussions in practice and life - one of which was the normalisation of coloured as a separate and subordinate racial category (Jensen, 2008:21-22). But what had allowed this to occur in the midst of conceptual failure?

Notably, it required a steadfast belief in the existence of a racial essence to be found in the plural races - a belief that predated the implementation of apartheid and the unionisation of South Africa in 1910. The designated racial categories of the apartheid state were perceived by its makers as inherently natural (readily found in nature). While there might have been a realisation that the designated categories were, at times, hard to distinguish (with a number of individuals challenging their racial classification as provided by state officials [see Posel, 2001]), the government was seemingly under the impression that more thorough research and the addition of scientific knowledge could remedy the dilemma. In other words, it was rather an admission to incomplete knowledge than admission to faulty reasoning. ${ }^{14}$ But it might have been challenging for a government (and the people of South Africa)

14 Yvonne Erasmus and George T.H. Ellison argue that the cases of the Review Board illustrate a "lack of explicit references to science". Based on the absence of science in these cases, Erasmus and Ellison postulate that there was an admission by the state that race was a social construct (2008:451). In this case, I argue there was a continued need and concerted effort to underpin this social construct of race with scientific evidence in the 1950s (and even in the 1960s). The close connection between science and society as shaping notions of race and racial categorisation was a dialectical process. Science remained a major role player in efforts to conceptualise race in South Africa. 
to suddenly reconsider the existence of separate racial categories (and the racial essences to be found in these respective categories) when visual markers were so readily available for a deduction of inherent difference. For that reason, it often provided persuasive evidence to the officials of the apartheid state who examined "complexion, eyes, hair, features, and bone structure" (Bowker \& Star, 2000:210).

The prominence of visual markers in racial categorisation was, however, not developed by the apartheid state. It stemmed from early scientific engagements with the natural world. Anthropological engagements in the late 1800s and early 1900 s - and this was particularly the case for the subfield of physical anthropology relied on visible physical characteristics to identify and define human, or rather racial categories. It was already in the mid-1800s that Paul Broca had associated the type of skull with specific skin tones and hair texture. Throughout the 1900s "racial scientists searched desperately for more and more trivial manifestations of race" - including the "curliness or twist in the hair" as a fundamental factor of division (Malik, 1996:120). These visible characteristics were related to a human hierarchy ranging from the social inferior to the superior - embodied by the very specific characteristics of "a straight face [rather than a forward-jutting face], more or less white skin and straight hair" (Gould, 1981:84). In the field of physical anthropology, visual representations in conjunction with scientific measurements thus became primary elements for illustrating difference. Such visual illustrations were drawn upon to "identify and define the characteristic or typical features of race, class or social group" (Green, 1984:4). As Elizabeth Edwards (2001:8) argues: "Fragments come to stand for a whole, as an expression of an apparent essence."

David Green argues that, through meticulous description and scientific knowledge, appearance was translated to fact: "the perception of a natural order of social structure and stratification was thought to be readily available in the evidence of the human body" (1984:6). In this sense, visual markers not only communicated bodily difference, but rather became representative of a host of biological as well as psychological, cultural and social differences. Green (1984:8) thus argues that these visual markers communicated "a complex system of social knowledge". In this sense, the representation of the "other" takes the form of complete portrayal where the visible becomes inherently linked to the social. Through a variety of forms of representation of individuals, the possibility exists to create "some greater class or classes to which the individual is seen to belong" - aiding a process of perceived homogeneity and uniformity (Gilman, 1985:204). In other words, visual markers and the law of racial aggregates support and often dictate, the process of racial classification. Visual markers (as related to race) is coupled with an "expectation of meaning" (Edwards, 2001:184), that is not informed by the medium itself, but in fact by an existing framework of interpretation - here referring to the "conscious and unconscious processes" (Tagg, 1993:4) of the onlooker. 
In this regard, Deborah Poole (2005:162) writes that visual representations, and particularly photography, were able to "craft racial common sense" by conflating "'popular' and 'scientific' understandings of embodied difference". For Pierre Bourdieu (2003:80), a "commonsense world" speaks of a broad "consensus on the meaning of practices", or that which has "settle[d] into our unconscious" (Bourdieu, 2003:79). The notion of race as commonsense is also a framework of interpretation for Deborah Posel (2001) to explain both the persistence of race in modern South Africa and its ability to function in the absence of pure "scientific" evidence or reasoning under apartheid. Posel (2001) and Dubow (2010) are in agreement that race had become habits of mind by the time apartheid was officially implemented - Dubow refers to the naturalisation of race, while Posel emphasises the commonsensical nature of race. Decades of global scientific engagements prescribing the measurement of skulls, facial features, bodily features and intelligence had ingrained the notion of human races, rather than a single human race, in the minds of the majority. Armed with this kind of "race knowledge", classification became accessible to laymen. Racial science had been translated for the public realm. No need for calipers or any other instruments of measurement, no need for scientists or textbooks for guidance: the populace had been educated on the many ways to spot the markers of racial difference and, more importantly, what those visual markers revealed of their bearer.

In his writings on neoliberalism, David Harvey (2006) briefly interrogates the notion of "commonsense understandings" in his attempt to understand how "systems of thought become hegemonic":

For this to occur not any old concepts will do. A conceptual apparatus has to be constructed that appeals almost 'naturally' to our intuitions and instincts, to our values and our desires, as well as to the possibilities that seem to inhere in the social world we inhabit. (Harvey, 2006:146)

\section{Debris and ruins}

Notions of racial difference coupled with added notions of an existing human hierarchy were able to develop into habits of mind (as both Dubow [2010] and Posel [2001] would refer to it). These habits of mind were nurtured and harnessed, resulting in (often legislated) discrimination around the world. Even under the guises of "separate but equal development" the case was no different for South Africa where any individual classified in a category other than "white" soon felt the hand of the state press down. These legislated state interventions under apartheid not only created categories to be regulated, but regulated those categories in a highly discriminatory fashion. In this regard, the construction of populations, here specifically referring to the coloured population, and the 
implementation of apartheid policies, are both viewed as "imperial formations" conceptualised by Stoler (2008:193) as being "defined by racialised relations of allocations and appropriations". For Stoler, such formations have a lasting impact and often produce debris or ruins, they "exert material and social force in the present" (Stoler, 2013:11). Imperial formations can thus more broadly be viewed as projects of ruination - defined as "a corrosive process that weighs on the future and shapes the present" (Stoler, 2008:194). It entails political projects "that lay waste to certain peoples and places, relations and things" (Stoler, 2008:196). These ruins are often produced by state projects that require "resources and planning [that] dictates how people are supposed to live" (Stoler, 2008:202). In this sense, Stoler's (2013) project of ruination can be related to Harvey's (2006) notion of creative destruction - entailing a continued effort to implement policies with ruinous effects.

Ruination thus embodies the "artefacts of destruction and violation" (NavaroYashin, 2009:5). As explained by Stoler (2008:193), the importance lies in "the longevity of structures of dominance, and the uneven pace with which people can extricate themselves". Today, national statistics still reveal discrepancies in access to health, education and a stable income when comparing the racial categories as inherited from the apartheid state. On a social level the coloured category, specifically in the Western Cape, are often plagued by "general processes of social exclusion based on derogatory stereotypes" (Jensen, 2008:11). In this regard, Bourdieu (1977:85) would refer to these long-lasting effects as "durable dispositions" - closely related to the long-lasting effects of imperial projects. These dispositions are defined by Bourdieu (1997:82) as "a past which survives in the present and tends to perpetuate itself into the future by making itself present in practices structured according to its principles”. Following Stoler (2008:194), one can thus think of ruination as "what people are left with".

\section{Conclusion: the spectre that haunts}

When you see, in a photograph or in a hat or in a footprint, the hand of the state ... you have seen the ghostly matter: the lost beloveds and the force that made them disposable. (Gordon, 2008:205)

Benjamin Dawids was measured by the Zoology Department of Stellenbosch University on 22 October 1937. By employing the prescribed techniques of global physical anthropology, Benjamin's eye, hair, and skin colour and the various indices of his "coloured male body" were translated to an all-encompassing racial data sheet. The name of Benjamin Dawids is not noted in any history book. Who can say what happened to him? However, it can be confidently assumed that he most likely became the target of apartheid policies. In this regard, he would have had to adhere 
to the Population Registration Act - to which Benjamin, a result of a mixed union, possibly posed a categorical problem; and subsequently would have been subjected to the rest of apartheid's imposing policies. A category was created and deployed against itself.

Time has passed: had Benjamin been alive today, he would have lived in a society where his movements and social interactions would not have been dictated by racial laws, but he would still have been designated as coloured on official government documentation. And should an immortal Benjamin Dawids have decided to apply to Stellenbosch University today, he would also have been requested to reveal his racial designation. Had he been a descendant of those who lived on Die Vlakte, those who were forcefully removed post-1964, he would have qualified for a bursary from this University - a bursary created "in addition to existing recruitment bursaries available to coloured, black and Indian students" (Stellenbosch University, 2015).

In 1993, Jacques Derrida proclaimed that the spectre of Marx was haunting Europe. One year after the release of this proclamation South Africa entered a political transition resulting, at least in theory, in a definitive break between an oppressive past and a new democratic present. But the effects of an outdated racial science and the official implementation of apartheid policies are still made manifest in our society more than two decades after the transition. The most obvious lingering effect, or daily practice, is that of racial classification - or rather the existence of fixed racial categories to aid such classification. Closely related to these racial categories are visible discrepancies in access to resources and relations to poverty. It is a history that has proven to be "residual and tenacious" (Stoler, 2008:211). The spectre of racial classification is haunting South Africa.

Derrida draws on "the figure of the ghost to pursue that which haunts like a ghost and, by way of this haunting, demands justice, or at least a response" (Del Pilar Blanco \& Peeren, 2010:9).

When I confronted the instruments used to measure Benjamin Dawids and so many others the feelings of shock and horror were accompanied by a form of recognition. These instruments were immediately recognised as the indicators of so-called racial attributes. The spectre of racial classification was made manifest in these objects. It embodied the ruins of an archaic science, but also the ruins of a society that functions according to racial classification. When age-old, archaic scientific objects can cause an upheaval, when it is able to haunt, its ghost has not been laid to rest. In this regard, the objects retained a sense of Freudian repression rather than a simple history. It illuminated "that which appear[ed] absent", but was in fact "a seething presence" (Gordon, 2008:115); that which "is dominant but hard to see" (Stoler, 2008:211). In this regard, the notion of race as common 
sense, illustrated beyond the apartheid state through a legacy of "race knowledge" that dictates definitions of race as rampant in public perception (and confirmed through its continued salience in institutional use), becomes a seething presence.

For Derrida, in particular, "the ghost or spectre is seen to signify precisely that which escapes full cognition or comprehension" (Del Pilar Blanco \& Peeren, 2013:9). The confrontation, the active haunting that demands a response, becomes possible only where the ghost is seemingly comprehended. The comprehension of a ghostly presence, however, requires a reflexive engagement with history. For Gordon (2008:118), an effective history allows us to "[put] life back in where only a vague memory or a bare trace was visible to those who bothered to look" (Gordon, 2008:118). It requires interrogation, confrontation, and finally comprehension - an awareness of the processes that produced ruins, for "ruins are not just found, they are made" (Stoler, 2013:20). It is for this reason that Stoler (2013:14) makes a case for the importance of ruins as "privileged sites of reflection". Through the instruments for measurement, the spectre of racial classification was made manifest and a moment for reflection presented itself. Another recent illustration of the spectre made manifest has been the Rhodes statue located on the campus of the University of Cape Town. For decades, this statue stood in silence, present but largely ignored, and then it became hyper-visible. Its presence became most profound as a symbol of oppression and the eventual removal of the statue became a way to address the past. In the post-apartheid South Africa, remembering is seemingly as threatening as forgetting.

For some, an acknowledged haunting "represents an opportunity to understand and come to terms with mystery", for once the "monster becomes visible; the ghost [can be] laid to rest" (Holloway \& Kneale, 2008:300). The alternative - one that is seemingly often pursued - is repression upon confrontation. We erase and silence before we have truly comprehended. We remove all reminders of that which causes discomfort. In this regard, we can pack away the scientific instruments used for measurement where they are hard to locate, or where they cannot confront, we can remove statues because their presence becomes an imposing burden, we can attempt to erase parts of history in order to move forward and thereby unleash a haunting onto the future. But this comes with a note of caution. As Christine Tan (2013:4) argues: "... blinded as we are, we fix our gaze towards paths that tend to imprison us further." 


\section{References}

Bertillon, A. 1895. Identification anthropométrique: Instructions signalétiques (Vol. 1). Melun, France: Typographie-Lithographie Administrative.

Blignaut, A.P. c.1940. Die Leerbekwaamheid van die Graaff-Reinetse Kleurling in vergelyking met dié van die Blanke en Naturel. Unpublished MA Thesis, Stellenbosch University.

Bourdieu, P. 2003 [1977]. Outline of a Theory of Practice. Cambridge, UK: Cambridge University Press.

Bowker, G.C. \& Star, S.L. 2000. Sorting Things Out: Classification and its consequences. Cambridge, MA: The MIT Press.

Bracken, C. 1997. The Potlatch Papers: A colonial case history. Chicago, IL: Chicago University Press.

Bruwer, J.P. van S. 1956. Agendas, notules en besluite. Nie-blankes in Wes-Kaapland. Bruwer Collection. PV123 1/5/1. University of the Free State, Bloemfontein, South Africa: National Party Archives.

Bruwer, J.P. van S. 1958. The races of mankind. In: J.P. van S. Bruwer, J.C. Grobbelaar, H.J. van Zyl \& R.F. Weaver. Race studies (ethnography) (Differentiated Syllabus) For standard VII. Johannesburg: Voortrekker Pers Bpk.

Bruwer, J.P. van S. 1964. Die posisie van die Kleurlingbevolking: Historiese agtergrond. In: S.P. Cilliers (ed.). Wes-Kaapland: n Sosio-ekonomiese studie (Western Cape: A Socio-Economic Study). Stellenbosch, South Africa: Kosmo Publishers.

Chia, R. 2000. Discourse analysis as organizational analysis.Organization, 7(3). https://doi.org/10.1177/135050840073009

Cilliers, S.P. (ed.). 1964. Wes-Kaapland: in Sosio-ekonomiese studie (Western Cape: A Socio-Economic Study). Stellenbosch, South Africa: Kosmo Publishers.

Comaroff, J. \& Comaroff, J. 1992. Ethnography and the Historical Imagination. Boulder, CO: Westview Press.
Daly, H.V. 1961. Phenetic classification and typology. Systematic Zoology, 10(4): 176-179. https://doi.org/10.2307/ 2411615

Del Pilar Blanco, M. \& Peeren, E. 2010. Introduction. In: M. del Pilar Blanco \& E. Peeren (eds). Popular Ghosts: The haunted spaces of everyday culture. London: Continuum.

Department of Zoology. 1937. Data sheets: Coloured males of Stellenbosch. C.S. Grobbelaar collection, 250.N1(64-194). J.S. Gericke Library Document Centre, Stellenbosch University.

Dönges, T.E. 1959. T.E. Dönges-collection, 1909-1967. Vol. 444, A1646. Cape Town: National Archives.

Dubow, S. 1995. Scientific Racism in Modern South Africa. Cambridge, UK: Cambridge University Press.

Dubow, S. 2010. South Africa: Paradoxes in the place of race. In: A. Bashford \& P. Levine (eds). The Oxford Handbook of the History of Eugenics. Oxford, UK: Oxford University Press.

Dubow, S. 2014. Apartheid, 1948-1994. Oxford, UK: Oxford University Press.

Du Plessis, R. 2015. Beyond a clinical narrative: Casebook photographs from the Grahamstown Lunatic Asylum, c.1890s. Critical Arts, 29(1). https://doi.org/10.1080/ 02560046.2015 .1102258

Edwards, E. 2001. Raw Histories: Photographs, anthropology and museums. Oxford, UK: Berg.

Eikestadnuus. 1955. "Studie van nie-blankes se posisie in W.P.: Universiteit onderneem omvattende ondersoek.” 11 November:1-2.

Eikestadnuus. 1968. "Ons lesers se briewe: Stellenbosch Slum Area." Paul Edmunds. 29 November:7.

Eiselen, W.W.M. 1955. Die Kleurling en die Naturel. In: Die Kleurling in die SuidAfrikaanse samelewing: Referate gelewer 
op die sesde jaarvergadering van die SuidAfrikaanse Buro vir Rasse-Aangeleenthede (SABRA). Pretoria and Stellenbosch, South Africa: SABRA. 109-125.

Erasmus, Y. \& Ellison, G.T.H. 2008. What can we learn about the meaning of race from the classification of population groups during apartheid? South African Journal of Science, 104(11-12). https://doi.org/10.1590/ S0038-23532008000600016

Faubion, J.D. (ed.). 2001. Michel Foucault: Power. Essential works of Foucault, Vol. 3. New York: The New Press.

Fick, M.L. 1929. Intelligence test results of poor white, native (Zulu), coloured, and Indian school children and the educational and social implications. South African Journal of Science, 26.

Fields, B.J. 1982. Ideology and race in American history. In: J.M. Kousser \& J.M. McPherson (eds). Region, Race, and Reconstruction: Essays in honor of C. Vann Woodward. New York: Oxford University Press.

Findlay, G. 1936. Miscegenation: A study of the biological sources of inheritance of the South African population. Pretoria: Pretoria News \& Printing Work.

Fischer, E. 1913. Die Rehobother Bastards und das Bastardierungsproblem beim Menschen: Anthropologische und ethnographische Studien am Rehobother Bastardvolk in Deutsch-Südwest-Afrika. Graz, Austria: Akademische Druck-u. Verlagsanstalt.

Fischer, E. 1931. Variable characters in human beings. In: B. Erwin, E. Fischer \& F. Lenz. Human heredity. E. Paul \& C. Paul (transl.). New York: The Macmillan Company.

Ford, C.L. \& Airhihenbuwa, C.O. 2010. Critical race theory, race equity, and public health: Toward antiracism praxis. American Journal of Public Health, 100:S30-S35. https://bit.ly/2TPfOEJ

Freud, S. 1955 [1919]. The "Uncanny". In: S. Freud. From the history of an infantile neurosis and other works. Vol. 17 (1917-1919). The Standard Edition of the Complete Psychological Works of
Sigmund Freud. J. Strachey, A. Freud, A. Strachey \& A. Tyson (transl.).

London: The Hogarth Press.

Gilman, S. 1985. Black bodies, white bodies:

Toward an iconography of female sexuality in late nineteenth-century art, medicine, and literature. Critical Inquiry, 12(1). https://doi.org/10.1086/448327

Goldberg, D.T. 2016. Racial Subjects: Writing on race in America. New York: Routledge. https://doi.org/10.4324/9781315865751

Gordon, A.F. 2008. Ghostly Matters: Haunting and the sociological imagination. Minneapolis, MN: University of Minnesota Press.

Gould, S.J. 1981. The Mismeasure of Man. London: W.W. Norton.

Green, D. 1984. Veins of resemblance: Photography and eugenics. The Oxford Art Journal, 7(2):3-16. https://doi.org/ 10.1093/oxartj/7.2.3

Green, L.; Condy, J. \& Chigona, A. 2012. Developing the language of thinking within a classroom community in inquiry: Pre-service teachers' experience. South African Journal of Education, 32(3). https://doi.org/10.15700/saje.v32n3a583

Grobbelaar, C.S. 1948. Anthropometry and its role in South Africa. Presidential address to Section 'D' of the South African Association for the Advancement of Science. South African Journal of Science, 44.

Grobbelaar, C.S. 1956. The physical characteristics of the Korana. South African Journal of Science, 53(4):97-143.

Harvey, D. 2006. Neo-liberalism as creative destruction. Geografiska Annaler (Series B, Human Geography), 88B(2):145-158.

Hertz, F. 1928. Race and Civilization. A.S. Levetus \& W. Entz (transl.). New York: The Macmillan Co.

Holloway, J. \& Kneale, J. 2008. Locating haunting: A ghost-hunter's guide. Cultural Geographies, 15(3). https://doi.org/10.11 77/1474474008091329

Jensen, S. 2008. Gangs, Politics and Dignity in Cape Town. London: James Currey. 
Jones, C. \& Porter, R. (eds). 1994. Reassessing Foucault: Power medicine and the body. London: Routledge.

Keen, J.A. 1952. Craniometric study of the Cape Coloured population. Transactions of the Royal Society of South Africa, 33(1). https://doi.org/10.1080/0035919 5109519876

Komitee insake Arbeid in Wes-Kaapland. 1959. Beskerming van Kleurlingarbeid, 1959-1961. KUS Vol. 35, 23/9. Cape Town: National Archives.

Komitee insake Arbeid in Wes-Kaapland. 1966. Agenda en Notule: Simposium oor Kleurlingarbeid. CRN Vol. 1/26, K3/5. Cape Town: National Archives.

Krogman, W.M. 1948. Physical anthropology and race relations: A biosocial evaluation. The Scientific Monthly, 66(4).

Malik, K. 1996. The Meaning of Race: Race, history and culture in Western society. London: Macmillan. https://doi.org/10.10 07/978-1-349-24770-7

Martin, R. 1914. Lebrbuch der Anthropologie: In systematischer darstellung mit besonderer berüksichtigung der anthropolgischen methoden für studierende ästze und forschungsreisende. Jena, Germany: Gustav Fischer.

Maré, G. 2014. Declassified: Moving beyond the dead end of race in South Africa. Johannesburg: Jacana.

Memmi, A. 1965. The Colonizer and the Colonized. H. Greenfeld (transl.). London: Earthscan.

Mitchell, W.J.T. 2012. Seeing through Race. Cambridge, MA: Harvard University Press. https://doi.org/10.4159/harvard.97806 74065352

Morris, A.G. 2008. Searching for "real" hottentots: The Khoekhoe in the history of South African physical anthropology. Southern African Humanities, 20.

Morris, A.G. 2012. Biological anthropology at the southern tip of Africa: Carrying European baggage in an African context. Current Anthropology, 53(5). https://doi.org/ $10.1086 / 662289$
Morris, A.G. \& Tobias, P.V. 1997. Physical anthropology: South Africa. In: F. Spencer (ed.). History of Physical Anthropology, Volume 2: $M-Z$. New York: Garland Publishing.

Navaro-Yashin, Y. 2009. Affective spaces, melancholic objects: Ruination and the production of anthropological knowledge. The Journal of the Royal Anthropological Institute, 15(1). https://doi.org/10.1111/ j.1467-9655.2008.01527.x

Olssen, M. 2010. The school as the microscope of conduction: Doing Foucauldian research in education. In: J.D. Marshall (ed.). Poststructuralism, Philosophy, Pedagogy. London: Kluwer Academic Publishers.

Parle, J. 2007. The voice of history? Patients, privacy and archival research ethics in histories of insanity. Journal of Natal and Zulu History, 24(1). https://doi.org/10.108 0/02590123.2006.11964140

Poole, D. 2005. An excess of description: Ethnography, race, and visual technologies. Annual Review of Anthropology, 34.

Posel, D. 2001. Race as common sense: Racial classification in twentieth-century South Africa. African Studies Review, 44(2). https://doi.org/10.2307/525576

Powerhouse Museum Collection. 2015. Set of 16 glass eyes in a tin by Rudolf Martin made in Germany in the late 19th century representing an early stage in the development of prosthetic eyes, 1880-1899. https://collection.maas.museum/object/ 38774 [Accessed 24 August 2015].

SABRA. 1953. Memorandum opgestel deur die Suid-Afrikaanse Buro vir RasseAangeleenthede (SABRA) ter voorlegging aan die Parlementêre Kommissie insake die Afsonderlike Verteenwoordiging van Kiesers. In: Union of South Africa. Report of the Commission to Enquire into the Subject Matter of the Separate Representation of Voters' Act Validation and Amendment Bill, Part II. A. Memoranda Received by the Commission to Enquire into the Subject Matter of the Separate Representation of Voters Act Validation and Amendment Bill, 1953.

\section{4 | RACE IN EDUCATION}


B.Official Memoranda, Statistical Returns and other Information Supplied to the Commission, 25-37. U.G. no. 20/1954.

SABRA. 1955. Resolusies. In: Die Kleurling in die Suid-Afrikaanse samelewing: Referate gelewer op die sesde jaarvergadering van die Suid-Afrikaanse Buro vir RasseAangeleenthede (SABRA), 126-128.

Sadie, F.A. 1942. The Relation between the learning ability and the degree of European blood in SA Non-Europeans. Unpublished MA Thesis, Stellenbosch University.

Scott, J.C. 1998. Seeing Like a State: How certain schemes to improve the human condition have failed. New Haven, CT: Yale University Press.

Sharp, J. 1981. The roots and development of volkekunde in South Africa. Journal of Southern African Studies, 8(1). https://doi. org/10.1080/03057078108708032

Soudien, C. 2006. Racial discourse in the Commission on Native Education (Eiselen Commission), 1949-1951: The making of a "bantu" identity. Southern African Review of Education with Education with Production, 11(1).

South African History Online (SAHO). 2016. Apartheid legislation 1850s-1970s. https://bit.ly/2N8qcG5 [Accessed 25 May 2016].

Stellenbosch University. 1924. Universiteit van Stellenbosch Jaarboek. Cape Town: Nasionale Pers.

Stellenbosch University. 2015. Applications open for SU's “Die Vlakte" bursary. https://bit.ly/1LvzqCR [Accessed 15 January 2017].

Stoler, A.L. 2008. Imperial debris: Reflections on ruins and ruination. Cultural Anthropology, 23(2). https://doi.org/10.11 11/j.1548-1360.2008.00007.x

Stoler, A.L. (ed.) 2013. Imperial Debris: On ruins and ruination. London: Duke University Press. https://doi.org/10.12 15/9780822395850
Tagg, J. 1993 The Burden of Representation: Essays on photographies and histories. Minneapolis, MN: University of Minnesota Press.

Tan, C.A.L. 2013. The Kristevan aesthetic of the sublime: Lapses of meaning from the meaningless abject. Paper presented at the 6th DLSU Arts Congress, held at the De La Salle University, Manila, Philippines, February.

UNESCO. 1950. Fallacies of Racism Exposed: UNESCO Publishes Declaration by World's Scientists. UNESCO Courier, 3(6/7):1-16.

UNESCO. 1952. The Race Concept: Results of an inquiry. Paris: United Nations.

Van der Spuy, J.S. 1959. 'n Studie van die liggaamsbou en liggaamsgroei van blanke en kleurlingseuns in die Westelike Provinsie, ouderdomsgroep 13 tot 17 jaar. Annals of the University of Stellenbosch, $35 \mathrm{~A}(2): 67-140$.

Van Wyk, G.F. 1939. A preliminary account of the physical anthropology of the "Cape Coloured People" (Males). Annals of the University of Stellenbosch, 17A(2):1-61.

Venter, C. 2009. The influence of early apartheid intellectualisation on twentiethcentury Afrikaans music historiography. Unpublished Master's Thesis (Musicology), Stellenbosch University.

Wilder, H.H. 1921. A Laboratory Manual of Anthropometry. Philadelphia, PA: P. Blakiston's Son \& Co.

Wilder, H.H. \& Wentworth, B. 1918. Personal Identification: Methods for the identification of individuals, living or dead. Boston, MA: The Gorham Press.

Winant, H. 2000. Race and race theory. Annual Review of Sociology, 26. https://doi.org/10.1 146/annurev.soc.26.1.169 


\section{${ }_{3}^{2} \mathrm{PR} \odot \mathrm{SS}$ VOLUMES IN THE SERIES}
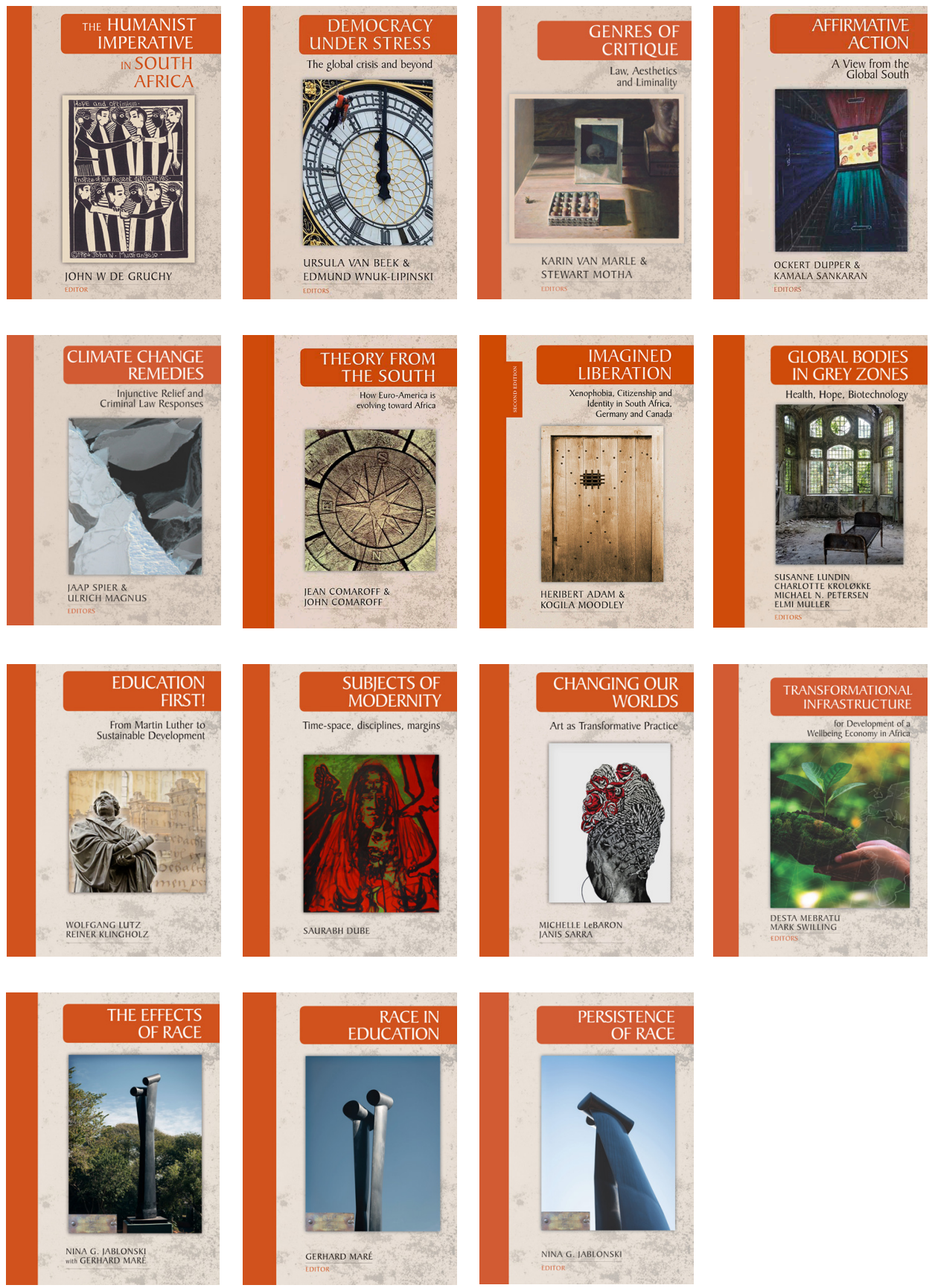